\title{
ЛЕКСИКА МАЙДАНУ НА СТОРІНКАХ УКРАЇНСЬКОЇ ПРЕСИ
}

\author{
НАТАЛІЯ ПОЛІЩУК \\ Рівненський державний гуманітарний університет, Дубно - Україна \\ SłOWNICTWO MAJDANU NA ŁAMACH PRASY UKRAIŃSKIEJ \\ NATALIA POLISZCZUK \\ Równieński Państwowy Uniwersytet Humanistyczny, Dubno — Ukraina
}

\begin{abstract}
STRESZCZENIE. W artykule rozpatrzono słownictwo terminologiczne, które pojawiło się w wyniku rewolucji na Majdanie oraz następujących później wydarzeń w Krymie i na Donbasie, i weszło jako integralna część do języka współczesnych mass mediów. Wyodrębniono grupy tematyczne, przedstawiono szczegóły użycia terminów w tekście autorskim.
\end{abstract}

\section{VOCABULARY OF MAIDAN IN UKRAINIAN PRESS}

\author{
NATALIIA POLISHCHUK \\ Rivne State Humanitarian University, Dubno - Ukraine
}

ABSTRACT. In this thesis the terminological vocabulary was reviewed. It appeared during the Revolution on Maidan, and armed events in the Crimea and Donbas. It has become an integral part of modern mass media; the thematic groups were found; the features of using terms in the author's text were illustrated as well.

$\mathrm{P}$ оль публіцистики та мови засобів масової інформації в динаміці сучасного українського лексикону дедалі зростає. Зміни в соціальній структурі держави, демократизація всіх галузей суспільного життя, відсутність цензури, пошуки нових засобів вираження всебічно відображені в мові сучасних мас-медіа. Тематична необмеженість газетно-публіцистичного стилю визначає надзвичайну широту й розмаїття його лексики. Цьому сприяє й розкутий мовний стиль сучасних журналістів, зростання рівня освіченості, досконале володіння іноземними мовами. Мова публіцистики засвідчує всі ті докорінні зміни, що відбуваються сьогодні в українському соціумі. Як зазначають сучасні дослідники мови, „можна без перебільшення твердити, що у витворенні сучасної української „новомови” перед веде саме публіцистика. Її можна вважати одним із тих потужних „тиглів”, у яких сьогодні „варять” новий літературний взірець української мови, нову взірцеву мовну норму, зокрема, лексичну та словотвірну"'.

Лексична система мови 3МІ - найбільш динамічна система сучасної української літературної мови. Загальновідомо, що у сфері ЗМІ найрізноманітніше та найсильніше виявлені процеси, що характеризують саме життя мовного організму; тут найбільше зосереджені інновації. І це природно, адже однією з основних функцій засобів масової інформації є інформативність, новизна.

Мова сучасних українських мас-медіа привертає увагу багатьох лінгвістів, оскільки вона — невичерпне джерело дослідження новітніх тенденцій у розви-

${ }^{1}$ Н. Ф. Клименко, С. А. Карпіловська, Л. П. Кислюк, Динамічні прочеси в сучасному украӥнському лексиконі, Київ 2008, с. 9. 
тку сучасної літературної мови. Одним із найпомітніших процесів, що відбуваються в мові сьогодні, $є$ процес активного поповнення лексики. Мова сучасної публіцистики віддзеркалює багатофункційність національної мови, ступінь iii інтелектуалізації, зокрема через поширення термінів з різних галузей знань.

Термінологічна лексика, уживана в професійній сфері й зафіксована в спеціальних словниках, починає нове життя в мові ЗМІ. „Фіксування такої лексики в досліджуваних джерелах $є$ показником літературно-нормативної адаптації термінів, випробування на міцність, тривкість запозичень, органічне входження до словотвірної системи української мови"'. Найпомітніше місце належить суспільно-політичній термінології, функціонування якої в мові ЗМІ забезпечує характерні для сьогодення тенденції інтелектуалізації літературної мови.

Нові слова і вислови були в полі зору О. Стишова, О. Семенка, С. Караванського, Ж. Колоїз, 3. Фоміної. Поняттям „суспільно-політична лексика” послуговується чимало українських (А. Бурячок, В. Жайворонок, О. Мороз, І. Холявко, I. Кочан) і зарубіжних (Т. Крючкова, I. Протченко, Н. Юзефович) лінгвістів. Покликаючись на них, авторка цієї наукової розвідки дослідила функціонування суспільно-політичної лексики й термінології в ЗМІ та зробила висновки щодо того, які саме інновації політологічного характеру переважають у мові мас-медіа, зокрема дослідила виникнення й функціонування термінологічної лексики Майдану та лексики, що окреслює подальші воєнні дії на південному сході країни, зробила висновки про те, які терміни переважають у мові сучасної преси.

Об'єкт дослідження - суспільно-політична лексика й термінологія, що функціонує в мові сучасних мас-медіа, зокрема терміни, народжені Майданом, дібрані 3 газет „Дзеркало тижня” (далі - ДТ), „Високий Замок” (далі - В3), „Українська правда" (далі - УП) за період 2013 - 2015 рр.; предмет дослідження - функції аналізованих одиниць у газетному тексті. Мета роботи - простежити появу нової лексики й термінології в публікаціях політичного спрямування, виявити ії тематичні групи, з'ясувати особливості вживання в публіцистичному тексті.

Авторка цієї студії робить спробу показати, де доречно використовувати неологічну лексику, а де їі бажано уникати, з'ясовує, які з лексичних новотворів $\epsilon$ вдалими, виправданими 3 огляду на мовну культуру, а які треба вживати обережно. Ця проблема актуальна, оскільки пов'язана з питанням мовної норми.

У часи великих, докорінних перетворень у житті того чи того народу 3'являється багато нових слів та понять. Потреба в нових словах зумовлена насамперед позамовними чинниками, зокрема політичними змінами в суспільстві.

Усеукраїнський протестний рух під назвою Революиія гідності, що розпочався в листопаді 2013 р. з Євромайдану й переріс у збройну боротьбу проти режиму Януковича, став одним із найпотужніших протестних рухів останніх десятиліть в Україні. Майдан спалахнув не тільки через зупинку євроінтеграції. Чорне крило неуцтва й невігластва, повсюдного здирництва, казнокрадства, сваволі „правоохоронних” органів, узурпації влади та диктатура нависли над Україною. Отруйною змією в суспільне життя почала вповзати зневага до української мови та всього українського. Академічна наука, що ніколи не належала до державних пріоритетів, узагалі була забута. Тому люди повстали.

Революція на Майдані й наступні за нею події в Криму та на Донбасі ввели в ужиток українців цілу низку нових слів і понять. Прихильники й противники Майдану, автори-журналісти, відомі політологи та громадські діячі не скупили-

${ }^{2}$ О. А. Стишов, Украӥнська лексика кінця ХХ століття (на матеріалі мови засобів масової інформації), 2-ге вид., переробл., Київ 2005, с. 32. 
ся на креатив і винахідливість, завдяки чому події, що розділили історію країни на „до” і „після”, отримали й власні мовні визначення. Вплив потужної розмовної стихії, яку називають „кузнею” лексики, найбільше охопив сферу ЗМІ. Провідні видання висвітлювали події Майдану з максимальною достовірністю, добираючи найяскравіші лексичні новації.

У мові сучасної періодики виділяємо активне функціонування таких термінологічних груп:

1) суспільно-політичні терміни - це загальновідома суспільно-політична лексика 3 нейтральною аксіологічною конотацією: сепаратизм, геноцид, анексія, президентські вибори, голосування, вердикт, істеблішмент, санкція, бюрократія, децентралізачія, олігархія, парламентсько-президентська республіка, тероризм, агресія, експансія, авторитаризм, плебісцит, анилюс, плутократія тощо, порівн. їхнє функціонування: Досить поверхового знання про Крим плюс деякої загальної ерудииї й елементарної логіки, щзоб зрозуміти, яким величезним ризикам піддає Росію анексія Криму. I при цьому вона не приносить ніяких реальних дивідендів! (ДТ, № 15, 25 квіт. 2014 р.); Народний депутат Олег Ляшко заявив, щзо народні депутати Сергій Горохов і Володимир Медяник, підконтрольні лідеру фракиії Партії регіонів О. Сфремову, підтримують сепаратизм та тероризм. Зокрема, депутат Горохов у Москві публічно підтримав проведення сепаратистського референдуму на Луганщині (УП, 22 черв. 2014 р.); Анилюз Криму - ие грубе порушення всіх норм міжнародного права і всіх традицій, щзо склалися в Свропі. Світ ц̧ього не проковтне, - Андрій Зубов, відомий російський історик, який виступив проти анексії півострова (В3, № 86, 19 - 25.06.2014); Хоча з Будапешта доносяться мало не найгучнімі в СС стогони з приводу втрат через санкції проти Росії та відповідного продовольчого ембарго РФ, справи в економіці Угорщчни аж ніяк не найгіриі. Ба, більше, за даними Свростату, Угорщина - один із лідерів Свросоюзу з економічного зростання минулого року (ДТ, № 24, 03 лип. 2015 р.);

2) аксіологічно марковані суспільно-політичні лексеми - сталі суспільнополітичні поняття та реалії з гнучкою конотативною зоною, що відображають динаміку цінностей суспільно-політичного процесу: споконвічна мрія, фальшування, провал влади, украӥнофоб, бюрократично-мафіозний клан, антитерористичний рух, персона нон-грата, кадрова револючія, корупційна схема тощо, напр.: Письменник Віктор Суворов (він же Володимир Різун) - у післямові до книги „,Остання Республіка”.: Росія або загине, розпадеться на шматки та знищить себе у війні бюрократичних та мафіозних кланів, або скине свою злодійську владу за зразком Украӥни. Слава Україні! (В3, № 82, 12 -18.06.2014); Можу стати жертвою критики, але жодного прізвища до кінця виборчої кампанії від мене не почуєте, - заявив Петро Порошенко перед виборами. <...> А щзо говорити, розшифровують президентську мовчанку експерти, якщо з командою у Порошенка - дефіцит. 3 таким запасом гравців на велику кадрову революцію не розженешся (В3, № 80, 05 - 11.06.2014). Високопосадовці, включаючи прем' єр-міністра, міністра соцполітики та очільника НАК “Нафтогаз України”, доклали неабияких зусиль, рекламуючи запропоноване Кабміном підвищення комунальних тарифів. Насправді, як ми побачимо, конструкція, придумана Кабміном, є нічим іншим, як корупційною схемою, покликаною замаскувати майже повне збереження статус-кво (ДТ, № 11, 27 берез. 2015 р.);

3) хронофакти - лексеми, лозунги, лозунгові слова, власні імена, що характеризують конкретний факт, явище, подію, поняття, актуальні для певно- 
го відрізку часу. Такі лексеми діахронічно обмежені, мають сильні асоціативні зв'язки у свідомості мовців: Майдан, балаклава, „коктейль Молотова”, козак у касиі, зачистка, золотий батон, ультрас, силовик, бойовик, АТО (Антитерористична операчія), ДНР (так звана Донецька народна республіка) тощо. Порівн.: Ненависть. Найточніше визначення настрою на Майдані після 20 лютого. Вона палала в очах задимлених бійців із передової. Стискала серия тих, хто носив поранених, будував барикади і розливав по пляшках "коктейль Молотова". Вона здушувала горло тим, хто, дізнавшись про тривожні новини, примчав на перетворену на братську могилу розтерзану площу (ДТ, № 6, 21 лют. 2014 р.). Наталія Балюк, редактор тижневика “Високий Замок”: „Якщо АТО пробуксовує, якщо наші силовики-керівники, яких останнім часом називають “слабовиками”, не дають собі ради, нездатні рішуче діяти, віддавати притомні накази, то, може, варто справді щзось кардинально змінити?” (В3, № 80, $05-11.06 .2014$ ).

Досліджувана група хронофактів є найпоказовішою, адже вони виразно демонструють реакцію мови на революційні процеси. 3 цієї точки зору хронофакти можна вважати мовленнєвими новотворами (найчастіше - словосполученнями) з виразною тенденцією до фразеологізації. Такі лексеми, лозунги, лозунгові слова, гасла не тільки називають предмет, дію, ознаку, поняття, а й оцінюють відповідне явище дійсності, сигналізують про нейтральне, підкреслено позитивне або негативне ставлення до нього з боку автора. Тому хронофакти, використані в певному контексті за певних обставин, не тільки надають предмету новизни, а й одразу ж показують авторське ставлення до нього. У кожному окремому контексті їх використовують як виразний малюнок-характеристика кого- або чого-небудь - і позитивно- (Майдан, майданівецьь, ультрас, силовик, козак у касиі), і негативно-оцінного характеру.

Простежимо термінологізацію слова Майдан, що після Помаранчевої революції в листопаді 2004 р. на Майдані Незалежності, тим паче після останніх суспільно-політичних подій у нашій країні, стало, на думку Л. Ставицької, персоніфікованим, міфологізованим утіленням революції 3 людським обличчям в прямому й переносному значеннях ${ }^{3}$. Великий тлумачний словник сучасної української мови подає таке значення лексеми Майдан: „велике незабудоване місце в місті або селі; площа. // Базарна площа"4. 3МІ фіксують контексти, що свідчать про зміну значення, а саме: Майдан — „мітинг”, ,акція протесту", напр.: Не випадково, коли європейський парламент одностайно підтримав украӥнських людей на Майдані, депутат Свропарламенту Ребекка Хармс мала на плечах синьо-жовту тканину (В3, 12 - 18.12.2013); Майдан — „люди, українці, які беруть участь у мітингу” (метонімія за ознакою „територія (місце) ті, хто перебуває на ній”), Майдан — „явище, факт”, напр.: Саме слово Maidan вже не потребує перекладу іншими мовами світу. Це не «так званий Свромайдан», як його називає влада. Це сконцентрований вияв волі народу, його колосальна позитивна енергетика (В3, $19-25.12 .2013)$.

У сучасних газетних текстах часто натрапляємо на хронофакти негативно маркованого характеру, приміром: Луганда, Лугандонія, Донбабве (назва Луганської та Донецької областей після захоплення влади в них сепаратистами й початку збройних дій на Донбасі: ці номінації використовують противни-

\footnotetext{
${ }^{3}$ Л. О. Став ицька, Дискурс помаранчевої пристрасти, [в:] „Криитка”, Київ, 2005, № 3, с. 6.

${ }^{4}$ Великий тлумачний словник сучасної украйнської мови, уклад. і голов. ред. В. Т. Бусел, К.; Ірпінь 2007, с. 637.
} 
ки відокремлення Луганщини та Донеччини від України для окреслення фактів беззаконня і свавілля, що відбуваються там після початку сепаратистських виступів за аналогією з африканськими країнами); диванна сотня, диванні війська (визначення прихильників Свромайдану, які не виходили на вулицю, не брали участі в протесті, але підтримували протест в соцмережах, Інтернеті, активно закликаючи до нього; може означати зневажливе ставлення до тих, хто побоявся вийти на Майдан, а тільки розводив демагогію); правосеки (члени й бійці української націоналістичної, праворадикальної організації „Правий сектор”, що з'явилася під час Євромайдану і своїми діями сприяє радикалізації протистояння: саме „Правий сектор” почав боротьбу 3 „Беркутом” на вулиці Грушевського, а після революції вирушив воювати на Схід України; проросійські активісти правосеками та їхнім лідером Дмитром Ярошем лякають людей на всьому Південному Сході, обіцяючи, що ті розправляться з усіма, хто говорить по-російськи; у Росії правосекам створили образ ледь не найбільшого ворога й жаху для росіян); золотий батон (виріб у формі батона, виготовлений iз золота найвищої проби: дивний артефакт виявили в Межигір’ї після втечі звідти Януковича. Термін уживають для характеристики Януковича, його найближчого оточення й усіх казнокрадів і корупціонерів), порівн.: “Корупиія на нижньому і середньому рівні залишилася, вичікує $і$ спостерігає, як далі будуть проходити події. А подї будуть відбуватися тільки одним чином - жорстка боротьба. Досить вже тих, хто золоті батони купує. Ті, хто купує золоті батони, повинні “кришити батони" в місиях не таких віддалених", - заявив Яценюк на засідання уряду. (ДТ, № 13, 11 квіт. 2014 р.). „Наше завдання - боротьба проти угруповань терористів, які перебувають на території України. Гуляти, як у себе вдома, між містами вони не будуть. Це наша земля, а не Луганда чи Донбабве", - запевнив керівник добровольчого батальйону “Донбас" Семен Семенченко (УП, 25 квіт. 2014 р.). Віддали схід “донам” отримали „ЛуганДонію” (В3, № 75, 16 - 22.07.2015).

Провідні журналісти, відомі політологи, громадські діячі дають влучні характеристики лідерам Майдану, добре знаним політикам. У мові української журналістики домінують хронофакти з негативною або іронічною конотацією, напр.: куля в лоб (прізвисько прем'єр-міністра України Арсенія Яценюка, яке він отримав після свого виступу на Майдані; інтелігентний і освічений Яценюк, будучи одним з лідерів опозиції під час Євромайдану, намагався додати у свій образ не властивої йому революційності та агресії; номінація підкреслює провал таких спроб нинішнього прем'єра); вогнегасник (прізвисько Віталія Кличка під час Євромайдану, яке він отримав у протистоянні на вулиці Грушевського: Кличко намагався зупинити відкриті зіткнення між силовиками й активістами; політик закликав активістів повернутися на Майдан і продовжити протест у менш активних формах; слова Кличка не були сприйняті протестувальниками: його окропили з вогнегасника). Влучністю, дошкульністю, іронією просякнуті й такі назви, подаровані Майданом і війною на південному сході України, як беркутята, пташенята (співробітники розформованого нині спецпідрозділу МВС „Беркут”, які брали участь у зіткненнях з населенням під час Євромайдану; „Беркут” був головною силою влади проти Майдану і за численні факти перевищення повноважень під час вуличних боїв 3 людьми повністю дискредитував себе: його було розформовано після революції); зелені чоловічки (проросійські бойовики, озброєні люди, що з’явилися в Криму і на Південному Сході України разом з сепаратистськими настроями; номінація з'явивилася в Кри- 
му, де війська Росії в повному обмундируванні і зі зброєю блокували українські військові частини, патрулювали міста й все-таки навіть публічно визнавали своє російське походження; висадка ,зелених чоловічків” сприяла анексії Росією півострова). У відповідь на ,зелених чоловічків” з'явилися чорні чоловічки (українські збройні формування, часто добровільні, що воюють на Донбасі на стороні української армії; бійці не мають розпізнавальних знаків, назву отримали за кольором форми), порівн.: Беркутівиі розбили голову Юрію Луизенку, завдавши близько десятка ударів кийками. Лікарі діагностували у нього струс мозку, він у реанімащії. <..> Як повідомила його дружина, народний депутат Ірина Луцеенко, Юрій просить не мститися за нього "беркутятам", бо „ці хлопці самі залякані, вони звичайні виконавці” (ДТ, № 1, $17-24$ січ. 2014 р.). Чи блефує Путін, брязкаючи перед нашим носом зброєю (лише поблизу Калуги 15-метрова колона з бронетехніки стоїть) і висипавщи під кордон армію “зелених чоловічків"? (В3, № 86, 19 - 25.06.2014).

Оскільки сучасні ЗМІ віддзеркалюють політичну, ідеологічну, етнічну, конфесійну боротьбу, вони продукують нерідко так званий „чорний піар ”, у якому використовують оказіоналізми з негативно-оцінною експресією: бандерлоги, бандерівці (збірний образ проєвропейських, прозахідних українців, прихильників Майдану, противників режиму Януковича, серед їхніх опонентів і проросійськи налаштованої частини населення. Спочатку так називали українських націоналістів, прихильників ідеї Степана Бандери - українського політичного діяча, ідеолога й теоретика українського націоналізму. Але після Майдану, проросійськи налаштовані люди так називають усіх українців, які не підтримують їхніх поглядів. Ненависники Майдану вживають номінацію як синонім слова „фашисти”. Назву бандерівці використовують навіть на офіційному рівні. Так, президент Росії Володимир Путін стверджував, що бандерівці захопили владу в Україні; це повторював і Янукович, описуючи всі ,жахи революції” в Києві. Путін і Янукович використовують слово „,бендерівці ”, а не „,бандерівці〉”); майдауни (образливе позначення прихильників Євромайдану і Революції честі; використовують його люди 3 проросійськими поглядами, які стверджують, що прихильники Майдану „зомбовані” його ідеями, 3 „промитими мізками”, не хочуть працювати, а бажають тільки страйкувати на організованих Сполученими Штатами Америки мітингах і отримувати за це гроші); колоради (проросійські бойовики, які воюють на Сході України проти української армії, захоплюючи будівлі та міста; добре озброєні й підготовлені бійці, на думку їхніх супротивників, фінансовані Росією і спеціально закинуті в Україну для дестабілізації ситуації); ватники (проросійськи орієнтовані люди, які підтримують від’єднання від України іiі східних областей та Криму; вони не готові воювати за це, виступають за більш пасивні форми протесту, зокрема такі, як мітинги та демонстрації; найчастіше вони впевнені в тому, що владу в Києві захопили націоналісти й бандерівці, які хочуть приїхати до їхнього міста та вирізати все населення; ватники сподіваються, що Росія їм допоможе цього не допустити і обов'язково підніме пенсії); укри, укропи (зневажливе звертання до українців, які підтримують нову владу і орієнтацію на Захід у зовнішньополітичному курсі країни; номінацію використовують проросійськи налаштовані люди: вона має образливу конотацію), хунта (це про українську владу, що прийшла на зміну режиму Віктора Януковича; номінацію використовують проросійськи налаштовані люди, які вважають, що влада в Києві була захоплена незаконним способом - за допомогою військового державного перевороту, і тепер нові ке- 
рівники здійснюють каральні операції на російськомовному південному Сході країни), порівн.: Олег Покальчук: „Як ми житимемо у світі війни, і щяо це буде за життя? Найдраматичнішим воно буде для старшого покоління - чим старше, тим драматичніше. Бо давні фантомні болі знову оживуть у їхніх старіючих тілах і почнуть добивати тих, кого не добили Друга світова, Сталін і ГУЛАГ. Інша частина стареньких буде иьому несказанно рада, помираючи від надміру щастя з приводу того, щзо бандерівщі нарешті здохли. Отож вони неминуче скоро зустрінуться” (ДТ, № 18, 22 трав. 2014 р.); Виявилося, що у Пентагону є не тільки плани на випадок реальних надзвичайних ситуачій, але і програма протидії “зомбі-апокаліпсису”. <...> Вона лежить “у надрах секретної комп 'ютерної мережі американських військових" і називається СОNOP 8888. У документі містяться поради, як допомогти иивільній владі підтримувати законність і порядок після атаки колорадів і ватників на Сході України (ДТ, № 17, 15 трав. 2014 р.); Юрій Касьянов, активіст Aрмії SOS: ,, Українські силовики почали черговий наступ під Слов'янськом, щоб звільнити від терористів сусідні міста - Красний Лиман і Краматорськ. 3 нами воюють професіонали з Росії (озброєні ними "ватники" до уваги не беруться), перемогти яких можуть тільки такі ж професіонали” (УП, 13 черв. 2014 р.); „Хунта три дні тому захопила в полон мою людину. Ми вели переговори з приводу обміну на офіцерів украӥнської армії, СБУ і міліиії. Три дні українська хунта відмовляється міняти офічерів на ту людину, яку вони захопили. Наразі всі домовленості з украӥнською стороною порушено", - Ігор Безлер, командувач горлівських терористів” (ДП, № 19, 05 черв. 2014 р.).

Номінації, народжені Майданом, у мові сучасних мас-медіа нерідко продукують $з$ наперед визначеною стилістичною метою - за їхньою допомогою публіцисти моделюють високу експресивність мовлення, влучність, дотепність, іронічність, гротескність. Карнавальність Майданного фольклору цілком відповідала атмосфері розкутості, звільненню з тенет страху та байдужості, а сміх уже вкотре в історії став виразником і свідченням „неофіційної народної правди”.

Розглянувши терміни, номінації, народжені Майданом, що функціонують у сучасних українських мас-медіа, приходимо до висновку, що лексика детермінологізується, виконує не номінативно-дефінітивну, а стилістично-експресивну функцію, надаючи публікаціям певного колоритно-емоційного звучання, викликаючи в читача відповідні емоції, налаштовуючи його на сприйняття тих чи тих політичних подій, відповідно формує громадську думку.

Сфера сучасних українських 3МІ засвідчує: мова живе, еволюціонує, і завдання небайдужих до її долі журналістів-інтелігентів (вони ж бо належать до основних творців найрізноманітніших текстів) дбати, щоб мова за цих складних обставин залишалася собою, зберігала генетико-типологічні риси, оскільки мова 3МІ „стає еталонною, нормотворчим фактором, що впливає на формування норми сучасної літературної мови, а також на рівень етнічної мовної культури загалом"s.

\footnotetext{
${ }^{5}$ О. А. Стишов, Зазнач. джерело, с.101.
} 